\title{
Marine Pollution in Kuwait and Its Impacts on Fish-Stock Decline in Kuwaiti Waters: Reviewing the Kuwaiti Government's Policies and Practices
}

OPEN ACCESS

Edited by:

Jingzheng Ren,

Hong Kong Polytechnic University,

Hong Kong

Reviewed by:

Emanuele Pagone,

Cranfield University, United Kingdom

Manel Sansa,

National Institute of Applied Science

and Technology, Tunisia

*Correspondence: Mohammad E. A. Alqattan alqattan_moh@hotmail.com

Specialty section

This article was submitted to Multi-criteria Decision Making, a section of the journal

Frontiers in Sustainability

Received: 14 February 2021 Accepted: 31 May 2021 Published: 15 July 2021

Citation:

Alqattan MEA and Gray TS (2021) Marine Pollution in Kuwait and lts Impacts on Fish-Stock Decline in Kuwaiti Waters: Reviewing the Kuwaiti Government's Policies and Practices.

Front. Sustain. 2:667822.

doi: 10.3389/frsus.2021.667822

\author{
Mohammad E. A. Alqattan ${ }^{1 *}$ and Tim S. Gray ${ }^{2}$ \\ ${ }^{1}$ Institute of Aquaculture, University of Stirling, Stirling, United Kingdom, ${ }^{2}$ School of Geography, Politics and Sociology, \\ Faculty of Humanities and Social Sciences, Newcastle University, Newcastle upon Tyne, United Kingdom
}

Kuwait's "Blue Economy" project aims to help replace the country's oil and gas income by the sustainable development of its marine resources. The fishing industry has a prime place in the "Blue Economy" project, but nine of the main fish species in Kuwait have recently declined Rubian (Shrimp), Zobaidi (Silver Pomfret), Suboor (Hilsa Shad), Naqroor (Javelin Grunter), Hamoor (Orange-Spotted Grouper), Hamra (Malabar Blood Snapper), Halwayuh (Black Pomfret), Frush (Trout Sweetlips), and Kasur (Lizard Fish). This paper investigates the nature of pollution in Kuwaiti waters, examining its extent and causes, questioning whether or not it is a primary reason for fish decline, and discussing what measures could be taken to reduce or remove it. The data for this study were gathered from peer-reviewed articles, official Kuwaiti statistics and reports, and semi-structured interviews conducted in Kuwait with stakeholders in the fisheries including staff in the Kuwaiti Scientific Institute, the Fishery Protection Authority, the Environmental Protection Authority and governmental departments; fishers; and fishery business owners. The main finding of this study is that because of the weak government policies and practices to counter pollution, pollution does exist in Kuwaiti waters, but there is no solid evidence that it has a direct link to the decline in fish stocks. Overfishing, especially by illegal, unreported and unregulated (IUU) vessels, seems to be a more substantial cause of the decline in fish stocks.

Keywords: marine pollution, Blue Economy, Kuwait sea, Arabian Gulf, fishery decline

\section{INTRODUCTION}

Kuwait is located in the North of the Arabian Gulf, which is a strategic location in the region, with an extensive coastline $225 \mathrm{~km}$ long, increasing to $290 \mathrm{~km}$ when the associated islands are included; Kuwait has 10 islands (Warbah, Bubyan, Miskan, Kubbar, Qaroh, Um Almaradim, Failakah, Ouha, Shuwaikh Island, and Um Alnamil) (Bird, 2010) (Figure 1).

The Kuwaiti "Blue Economy" goal is to replace the country's oil income (currently $80 \%$ of its GDP) with marine and maritime investments (Trading Economics, 2019). Fishery production is one of the main sectors of the "Blue Economy" project in Kuwait and understanding the main causes for fish decline would help to enhance the sector, enabling the government and businesses to invest in it and thereby help to reduce the country's dependence on oil revenue (Mahdi, 2018). 


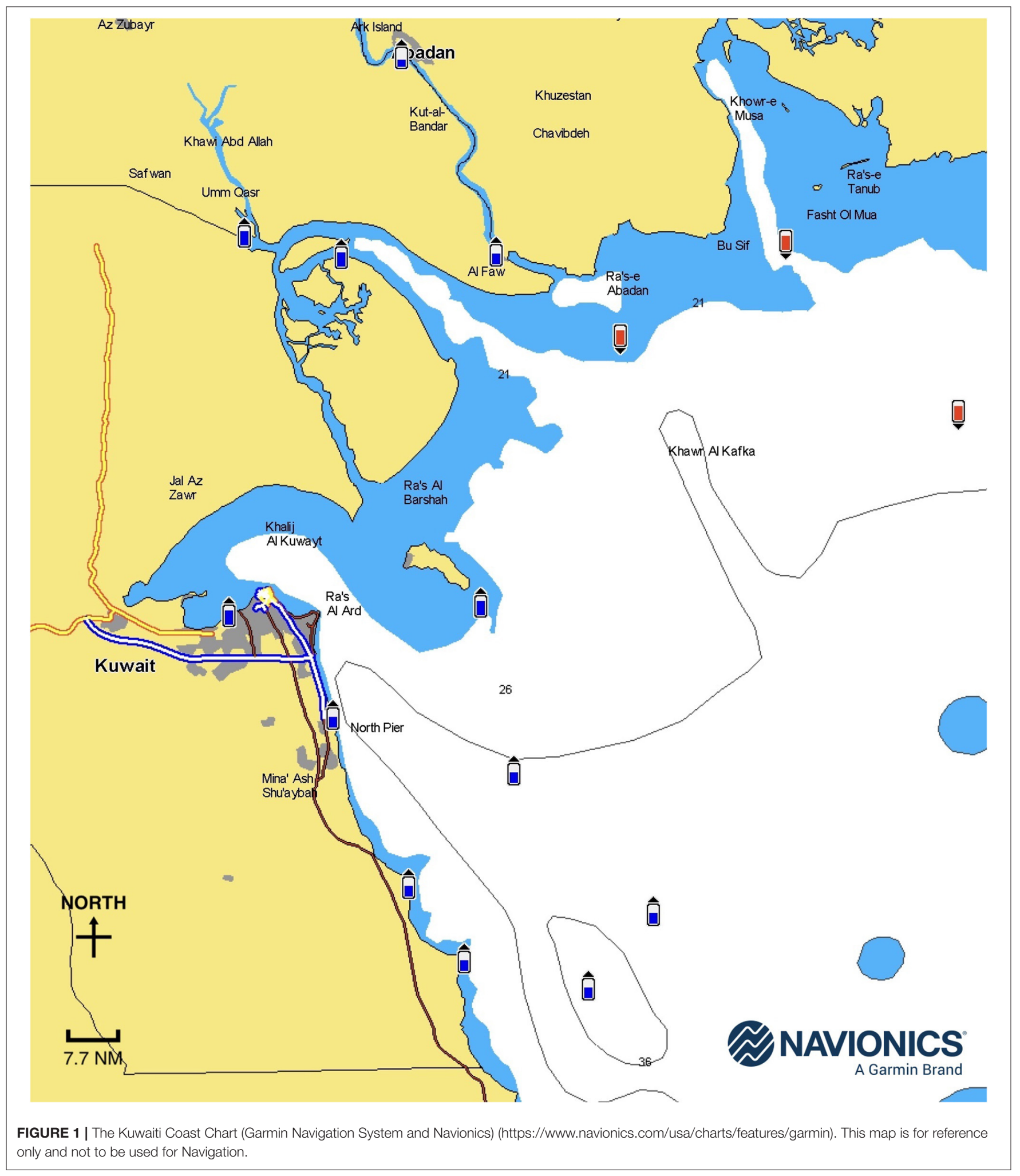

The main research questions of the paper are (1) what is the current state of health of the marine environment in Kuwait? (2) how does it affect the fishery? (3) are governmental actions effective in protecting fish stocks from threats to their health? It is important to answer these questions in order to understand the potential opportunities for the Kuwaiti government to invest in the fishing industry. Fish stocks are declining in Kuwait, and the suggestion is that the main causes are overfishing, especially by 
illegal, unreported and unregulated (IUU) vessels, and pollution. We have dealt with overfishing elsewhere (Alqattan et al., 2020): this paper is about pollution. We should note, however, that both overfishing and pollution are immediate or proximate causes, and behind both lie deeper causes within the system of natural resource management in the country. These deeper factors include the lack of good governance (to the point of alleged duplicity) and limited environmental awareness on the part of the public. The approach used in this analysis was to investigate both the proximate factor of pollution and the underlying factors of deficient governance and public awareness, and to discover how they are connected.

According to the United Nations Convention for the Law of the Sea (UNCLOS, 1982), "pollution of the marine environment means the introduction by man, directly or indirectly, of substances or energy into the marine environment, to result in harm on marine life." However, UNCLOS (1982) distinguishes between "deliberate" marine pollution or "dumping," and "incidental" marine pollution which occurs during the "normal" operations of maritime activity. This is an important distinction since it implies there is no culpability for "incidental" pollution, and that governments are not obliged to take action against operators responsible for it. In this study, we found evidence of pollution in the Kuwaiti waters caused by sewage, shipping waste, construction, and underwater explosions for oil searches. Applying UNCLOS' definition of pollution, these activities constitute deliberate disposal either by the Kuwaiti government or by companies with the knowledge of the government. Another source of pollution is the increased salinity caused by the shortage of fresh water from the Shat Al-Arab due to water dams in Turkey and on the Karon River in Iran which constitutes deliberate pollution that the Kuwaiti government has failed to address.

There were three steps in this study. The first step was to establish the extent to which marine pollution exists in the Kuwaiti waters. This entailed a literature review to identify the quality of the water; including its oxygen levels; factors which limit the rate of oxygen dissolving; pollutant chemicals in the water from waste and sewage discharge; and levels of salinity. The second step was to investigate the government's actions against pollution, including laws and regulations. The third step was to discuss wider issues such as why individuals, firms and communities pollute the marine ecosystem, and why the government's attempts to prevent marine pollution have not been effective.

In section The Nature of the Problem Drawn From the Literature, we set out the findings of previous studies on the condition of the Kuwaiti waters. In section Methods, we explain the methods of research we employed to obtain and analyze data. In section Results, we present our results from the interview data. In section Discussion, we discuss those results and compare them with the findings of previous studies. In section Conclusion, we conclude the paper with a summary of our findings and their implications for government.

\section{THE NATURE OF THE PROBLEM DRAWN FROM THE LITERATURE}

Drawing on the literature, the ecological condition of Kuwait waters and the extent and types of pollution in them are explained in this section.

\section{Decline in Fish Stocks in Kuwaiti Waters}

From the literature and the official annual reports provided by the public authority for agriculture affairs and fish resources (PAAFR) and the Kuwaiti central statistical bureau (CSB) (2017) and also by visiting official bodies in Kuwaiti, such as the Kuwaiti Institute of Scientific Research (KISR) and the Department of Fishery, we have noticed a significant decline in fish production between 1995 and 2019, as shown in Figure 2.

Researchers have reported a massive fall in fish stock levels in Kuwaiti waters in recent years. For example, Edmonds et al. (2021) stated that "marine turtles, vulnerable fish, coral reefs and coastal habitats are all experiencing clear decline.” Al-Baz et al. (2018) stated that Kuwait's fisheries landings have decreased from a high of 6,900 tons in 1995 to 3,100 tons in 2013-a decrease of $55 \%$. A large percentage of the decreased landings is attributed to two species, both captured primarily by gillnets: the Hilsa shad (Tenualosa ilisha) and the silver pomfret (Pampus argenteus). These two species now contribute only $10-15 \%$ of their previous annual landings volume of $\sim 1,000$ tons each. Several researchers, including Al-Foudari et al. (2013), Al-Husaini et al. (2015), AlZaidan et al. (2013), Almatar and Chen (2010); and Ben-Hasan et al. (2017), have linked the rise of fish prices to the shortage of fish production [see Figure 3, which illustrates the increase in fish prices in Kuwait from 2006 to 2019 (CEIC, 2019)].

However, this link cannot show definitive evidence of fish decline, as the rise in the price of any product, including fish, is affected by many different factors such as the demand for the product; fishing costs; global price increases; and population increases, not necessarily the decline of the product itself.

This section will analyze the production timeline since 1983 of the main species of fish and shrimp in Kuwait in order to understand the current situation of the main species of fish and examine whether the decline is linked to: (1) the fishing area of the species; and (2) the pollution type and source in the fishing area. The main fish species that have been analyzed in this section are set out in Table $\mathbf{1}$.

The main fish species in Table $\mathbf{1}$ have been analyzed to show the production figures from 1983 to 2019. Using the Kuwaiti CSB (2021) reports of Kuwaiti fish wealth, the following Figure 4 illustrates the rate of decline in the nine species whose stocks are diminishing.

From Figure 4 of the production timelines for the main fish species in the Kuwaiti fish market, we can see that the following species have suffered a steep decline since 1983: (1) shrimp production in panel (a) dropped from 3,900 tons in the 1980s to 600 tons in 2018; (2) Zobaidi production in panel (b) dropped from 1,100 tons in the early 1990s, which is just after the Gulf War Two, to 90 tons in 2018; (3) Suboor production in panel (c) dropped from 1,140 tons in the late 1990 s to 75 tons in 2018; (4) 


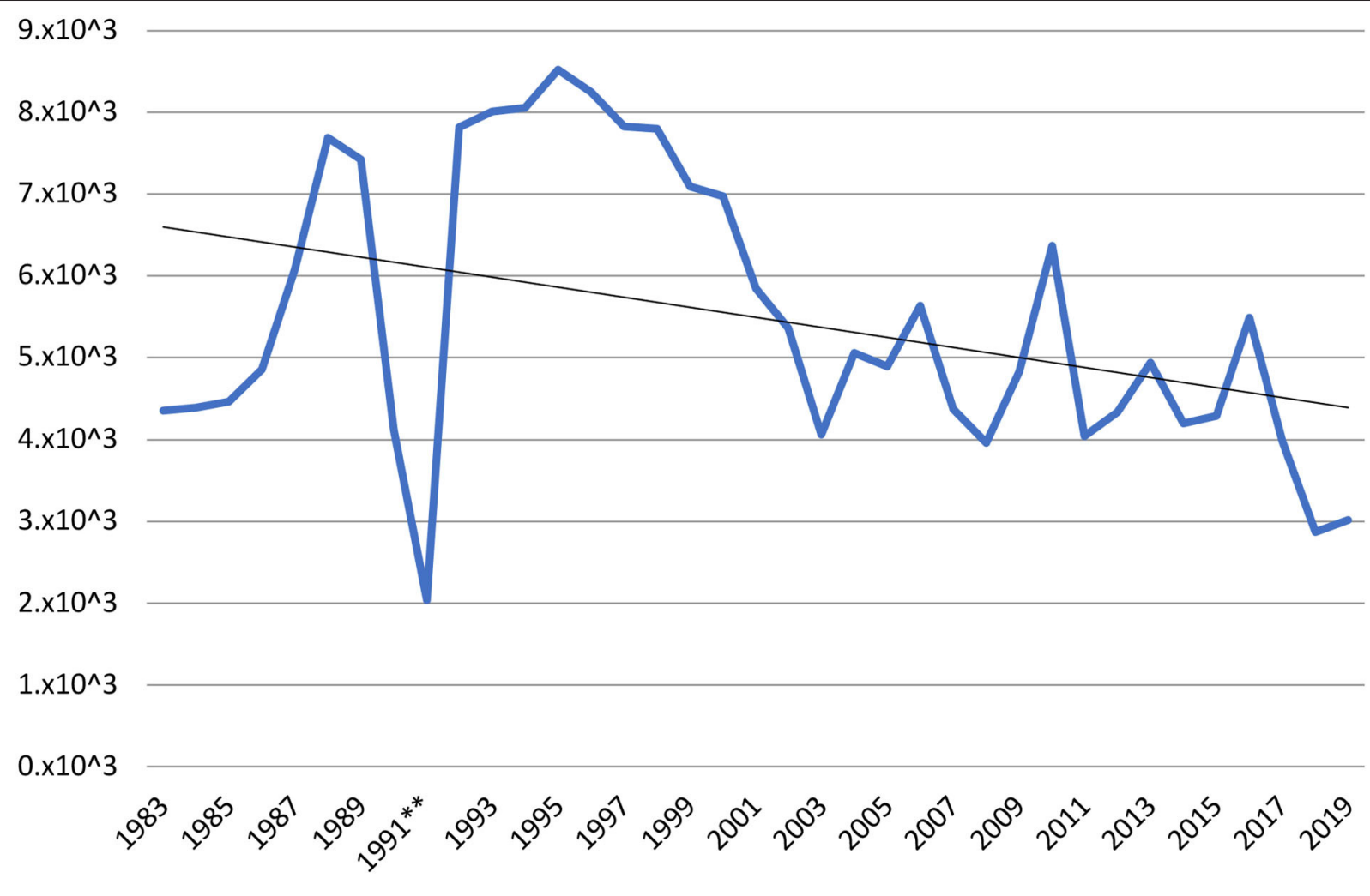

Total Catch in Tonnes _Linear (Total Catch in Tonnes)

FIGURE 2 | Fish and Shrimp production in the Kuwaiti waters from 1983 to 2019, showing the decline in fish production of the Kuwaiti fish in the Kuwaiti fish markets (Source: CSB, 2021).

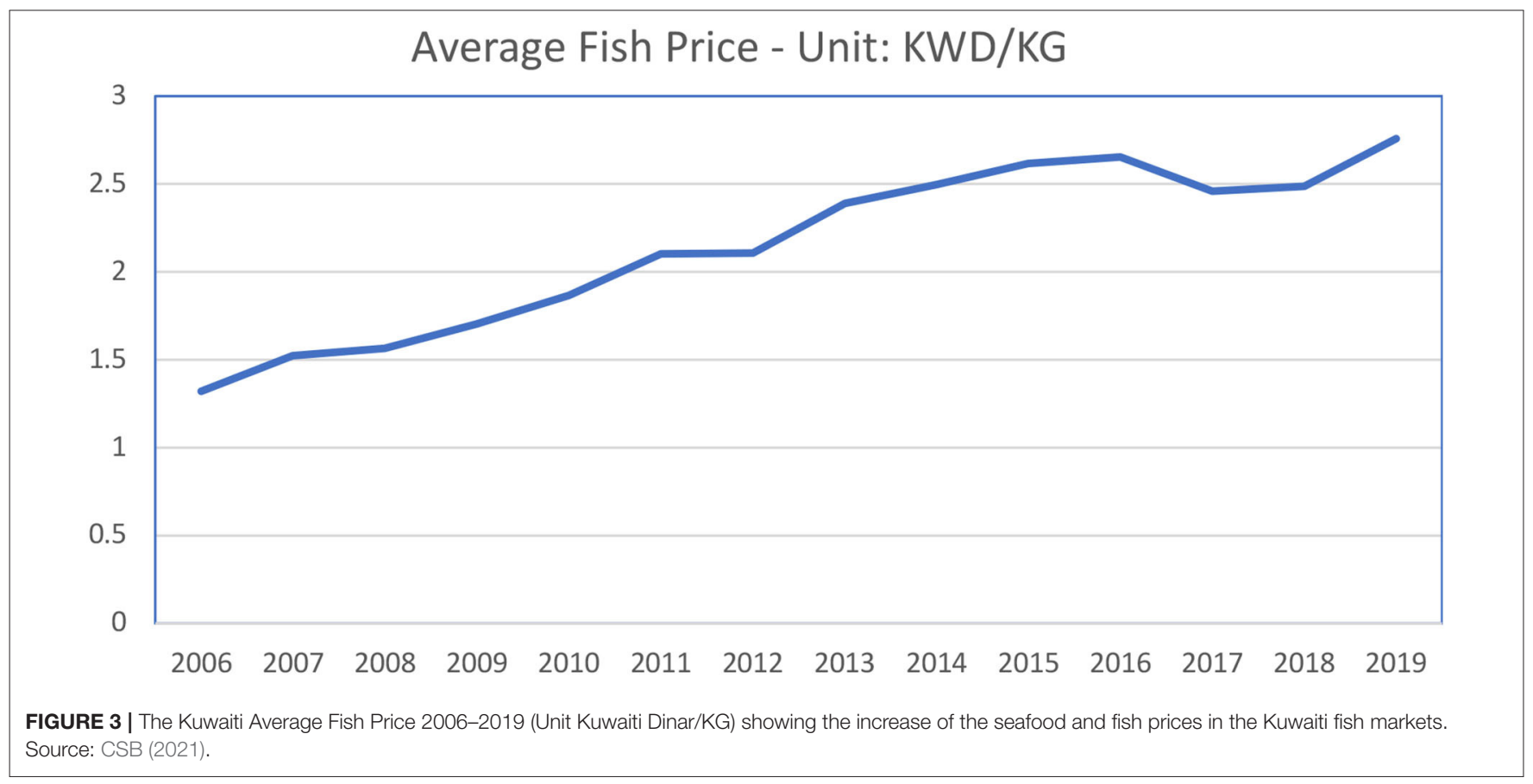


TABLE 1 | The main fish species in Kuwait.

\begin{tabular}{ll}
\hline Arabic local name & English name \\
\hline Rubian & Shrimp \\
Zobaidy & Silver pomfret \\
Suboor & Hilsa Shad \\
Naqroor & Javelin grunter \\
Hamoor & Orange-spotted grouper \\
Maid & Klunzinger's \\
Nuwaibi & Tigertooth croaker \\
Kannad & Kingfish \\
Hamra & Malabar blood snapper \\
Biah & Flathead mullet \\
HammamSeriolinanigrofasciata & \\
Shim & Fourfinger threadfin \\
Halwayuh & Black pomfret \\
Sha'm & Yellowfin seabream \\
Burtam & Grouper \\
Fursh & Trout sweetlips \\
Sha'ri & Spangled emperor \\
Sikin & Cobia \\
Smahi & Spotted croaker \\
Khubbat & Indo-Pacific king mackerel \\
Basij & Notched threadfin bream \\
Kasur & Lizard fish \\
Andak & King soldier bream \\
\hline
\end{tabular}

Naqroor production in panel (d) dropped from 240 tons in the late 1980s to 21 tons in 2018; (5) Hamoor production in panel (e) dropped from $\sim 530$ tons in the late 1980 s to 131 tons in 2018; (6) Hamra production in panel (f) dropped from 217 tons in the early 1980s to 18 tons in 2018; (7) Halwayuh production in panel (g) dropped from 290 tons in the mid-1990s to 12 tons in 2018; (8) Frush production in panel (h) dropped from 70 tons in the mid-1990s to 21 tons in 2018; and (9) Kasur production in panel (i) dropped from 55 tons in 2002 to 13 tons in 2018.

The remaining commercial fish species in Kuwaiti waters have either maintained a steady production level, or achieved an increase in production, suggesting there is currently no negative effect on those species by pollution or any other factor.

\section{Evidence of Pollution in Kuwaiti Waters}

Al-Mutairi et al. (2014) stated that "Kuwait Bay is suffering from different kinds of pollutions either from local or regional sources." Ali and Chidambaram (2021; p. 855) claimed that "the sources of pollution in the Kuwaiti Bays are oilbased, sewage, desalination, and natural oxidation-reduction processes [and] the level of toxin on four Kuwaiti fish species, Sheam, lobester, Speatty, and Nagroor may lead to cancer and non-cancer hazards on consumers." Also, Edmonds et al. (2021) said that "the main impacts on Kuwait biodiversity are coastal developments and sewage inputs." We list the five main sources of pollution below, which do not include nuclear pollution [Uddin et al. (2015) conducted a study by collecting water samples and fish species to find any signs of nuclear pollution in Kuwaiti waters, but found none].

\section{Sources of Marine Pollution in Kuwait Sewage}

According to several researchers, sewage discharge is the most important source of marine pollution in Kuwaiti waters (Naser, 2014; Lyons et al., 2015; Al-Sarawi et al., 2018). Devlin et al. (2015) conducted a 30-year modeling exercise on water quality in Kuwait's territorial waters and concluded that

\begin{abstract}
"There is a potential impact of large volumes of sewage effluent on an already impacted environment. Analysis of the data over 30 years shows a seasonal pattern to the data, with the dissolved nutrients increasing into the winter months, associated with increased rainfall. Long-term analysis shows a shifting baseline, with nutrient enrichment from both DIN and DIP evident from the late 1990s. The increase in DIN is dominated by the increase in NO3 in the early 90s but shifting to an increase in NH4 in the later 90 s through to the current period."
\end{abstract}

Lyons et al. (2015) stated that "water microbiological data demonstrates that sewage contamination has been a chronic problem for many years in Kuwait... the highest number of exceedances were observed around two stations S00 and S07 during the Mishrif crisis in 2009... Results indicated that bacterial counts regularly breach regional water quality guidelines. Sediments collected from a total of 29 sites contained detectable levels of co-prostanol with values ranging from 29 to $2420 \mathrm{ng} / \mathrm{g}$." Al-Sarawi et al. (2018) studied water samples collected from several locations during summer and winter months in Kuwaiti waters and concluded that in these locations, E. coli exceeded international water quality standards by almost 100 times, and that persistent failure to reach microbial water quality standards was due to high concentrations of fecal sterols. They also found that pollution from sewage in the Kuwaiti waters has resistance which exceeded the threshold of both the Kuwait Environmental Protection Agency (KEPA) standards and the European Union's Coastal Bathing Water Directive (CBWD). Al-Mutairi et al. (2014) reported the following incident: "In August 2009, the Mishrif sewage pumping station broke-down due to overload and huge amounts of raw sewage were discharged via emergency outlets into sea water and Kuwait Bay... The dissolved oxygen concentrations reached critical levels, below KEPA standards, for all six stations, indicating heavy pollution... Furthermore, the nutrient-rich waters discharged from Shatt Al-Arab... affects the Kuwait marine environment, particularly Kuwait Bay." Al-Yamani et al. (2020) reported that "The Kuwaiti environment has been increasingly affected by harmful marine mortalities which increased frequently the causes behind that were sewage, eutrophication, bacterial infection, algal blooms, hypoxic conditions, pollution and dredging."

\section{Oil Spills}

Al-Saad and Salman (2012) claimed that because the Arabian Gulf is an extremely busy shipping area for oil transportation, accidental spilling of oil is unavoidable. About 25,000 tanker 


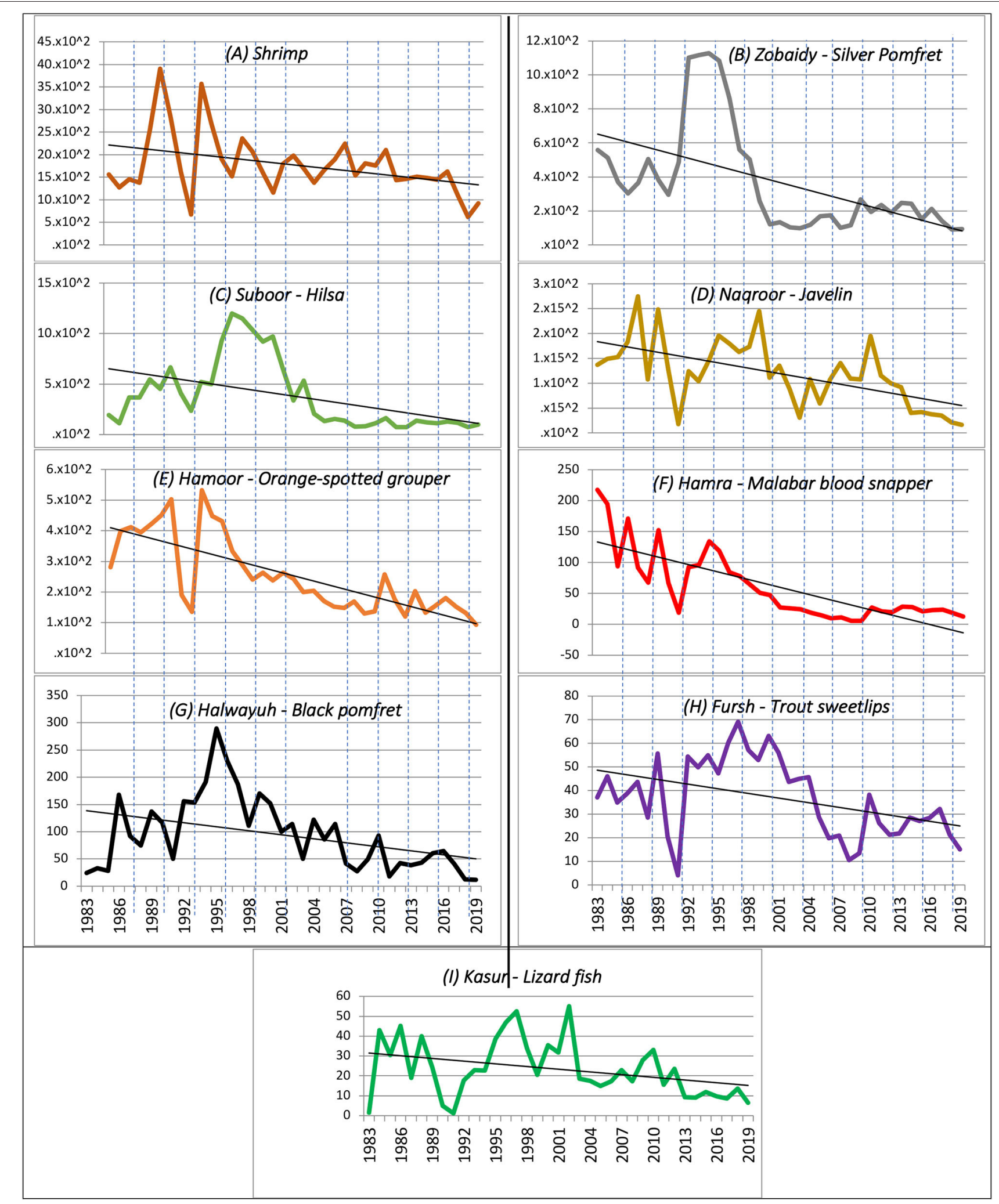

FIGURE 4 | The nine declining fish species total catch in tons in the Kuwaiti waters from 2000 to 2019. (A) Shows the decline of Shrimps. (B) Shows the decline of Zobaidi. (C) Shows the decline of Suboor. (D) Shows the decline of Naqroor. (E) Shows the decline of Hamoor. (F) Shows the decline of Hamra. (G) Shows the decline of Halwayuh. (H) Shows the decline of Frush, while (I) shows the decline of Kasur. Source: CSB (2021). 
movements sail in and out of the Strait of Hormuz annually, transporting $\sim 60 \%$ of all the oil carried by ships across the world. About two million barrels of oil are spilled annually from the routine discharge of dirty ballast waters and tank washing, partly due to the lack of shore reception facilities. Some major spills, either unintentional or as a consequence of military activities, have added occasional pulses of oil contamination to the ballast discharge background.

Oil spills from oil production operations are also major sources of pollution. Alshemmari (2021) reported that "the oil sectors in Kuwait are mainly along the coast and they are critical points of pollution sources of the Kuwaiti coast." Activities associated with oil traffic result in shores becoming heavily contaminated with oil residues, tar balls and trace metals. Many reports, pictures and videos have been posted in the social media about oil spills in the Kuwaiti sea (Marex, 2017), and in October 2018, KEPA claimed they sent a team to investigate, but the team denied there had been any spills (Kuwait News Agency, 2018). Aljazeerah News (2017) reported a crude oil spill of about 35,000 barrels in the South of Kuwait with which the Kuwaiti government struggled to cope. The report stated that Saudi Arabia and Bahrain joined the Kuwaiti team to deal with the leak as it reached those countries. Another effect of oil production is to raise sea water temperatures, which harm fish stocks. Al-Miqdadi and Al-Hoosh (2016) said "that the high water temperature in Kuwait and most of GCC [Gulf Cooperation Council] states is because of power production [oil] platforms which are located at the coast and dispose of hot water at sea." Al-Mutairi et al. (2014) recorded that "the seawater temperature in Kuwait Bay has increased by an average $0.6^{\circ} \mathrm{C}$ per decade, about three times higher than the global average rate reported by the Intergovernmental Panel on Climate Change (IPCC)... the higher temperature would affect the fish immune systems which might lead to fish kill."

\section{Ship Waste Dumping}

According to Al-Miqdadi and Al-Hoosh (2016), two kinds of ship waste dumping occur in Kuwaiti waters: chemical waste and vessel waste. Chemical waste is a systemic commercial practice: "the Kuwaiti sea suffers from the ships which dump chemical waste in the Kuwaiti waters without any control." Vessel waste is a random and opportunistic practice: ships dump overboard "fishing gears, oil, sewage and domestic waste when they pass through the Kuwaiti waters or just before arriving at one of the Kuwaiti harbors.”

\section{Dredging}

Al-Mutairi et al. (2014) found that "the water clarity is low in the Kuwaiti seawater, especially at the entrance of the Kuwaiti Bay, due to reclamation and dredging on the coast, turbid water discharge from Shat Al-Arab and from sand storms."

\section{Excessive Salinity}

Excessive salinity in Kuwaiti waters is due to the shortage of fresh water from Shat Al-Arab and the Karon River in Iran. Al-Husaini et al. (2015) stated that "the lack of fresh water incoming from Shat Al-Arab and from the Karon River in Iran, due to water dams, are the main reasons for the higher salinity of the Kuwaiti seawater." Hosseini et al. (2021) affirmed that "the Arabian Gulf, including Kuwait, is facing different types of stressors inducing marine pollution which affect the health of the marine environment and recently negative environmental effects of extensive desalination activity have been revealed which causes harm on the sea."

\section{Poor Performance of the Kuwaiti Environmental Protection Agency in Dealing With Marine Pollution}

A series of audits carried out into the work of KEPA in 2016 and 2018 by Kuwait's State Audit Bureau (SAB) were highly critical of it. The SAB is an independent organization established in 1964 to help the Kuwaiti parliament monitor and assess governmental performance and to report corruption. State Audit Bureau (2016) claimed that KEPA has recruited employees who are not qualified for their positions (Toumi, 2019), including some heads of department; that KEPA does not enforce the environmental law and regulations of 2014; that KEPA does not have laboratories to test samples and therefore wastes money on private laboratories to do the work; that KEPA does not have an effective process for analyzing environmental violations; that KEPA fails to monitor its data storage system; and that KEPA does not comply with the laws and regulations introduced in 2010 to protect marine diversity. State Audit Bureau (2018) claimed that KEPA's Judicial Officers have failed to comply with legal procedures when prosecuting people for environmental violations, which results in many cases being withdrawn in the courts and a massive drop in KEPA's financial income from fines. Edmonds et al. (2021) said that "knowledge about Kuwaiti marine biodiversity is incomplete and outdated because data... are insufficient."

\section{METHODS}

In this section, we explain our methods of obtaining and analyzing data. Methods of obtaining secondary data involved searching peer-reviewed and gray literature on pollution in Kuwaiti waters, including official reports detailing the ecological quality of Kuwaiti waters and government steps to improve it. After addressing the main research questions and themes, a critical approach was used to analyze the literature in order to cover all relevant themes (where high impact factor articles are prioritized) to address and satisfy each theme introduced. Methods of obtaining primary data included key informant (KI) interviews in Kuwait with 11 respondents who have relevant expertise and experience (see Appendix A for a copy of the questionnaire administered to the $11 \mathrm{KIs}$ ). KI-1 and KI-2 are researchers in pollution at the KISR; KI-3 works in one of the governmental pollution protection centres; KI-4 is a Kuwaiti fishing company owner; KI-5 is an environmental academic advisor for the Kuwaiti government; KI-6 is an expert on government environmental protection policy; KI-7 works in the KISR in the Department of Fishery Research; KI-8 is a Kuwaiti fishery business owner who depends on the fish Silver pomfret 
which commands the highest price in the market; and KIs-9,-10, and-11 are Kuwaiti fishermen who are experts in fishing areas and on a wide range of fish species in Kuwait. Our selection of all of these KIs was based on their direct knowledge of the marine environment in Kuwait including its pollution. All interviewees were conducted face-to-face and recorded, with permission from the interviewees. Before each interview, respondents were introduced to the aims of the study and its expected outcomes, and told their interview data would be treated as anonymous and confidential. The questions were semi-structured and discussed the evidence of fishery decline, the causes of the decline, the sources of pollution and its impacts on fish stocks, the quality of water and the responses of the Kuwaiti government to marine pollution. In addition, the lead author visited all the Kuwaiti islands and several beaches and coasts in Kuwait to view signs of pollution, oil spills sewage discharges, plastic waste and rubbish waste in Kuwaiti waters (Alqattan, 2018).

Analysis of the themes in the literature, the reports and the data from interviews was undertaken by means of NVivo software, which is a qualitative data analysis tool. The use of NVivo was to establish nodes based on the themes of the study such as fisheries decline, sources of pollution, water quality, and government responses to pollution. The contents of the interviews were linked, via the nodes and themes, to the backgrounds of interviewees and to the source and evidence of the literature and government reports in order to understand the full picture of the problem of marine pollution in Kuwait and its impact on fish stock decline.

\section{RESULTS}

This section presents the results obtained from the KI interviews.

\section{The Existence of Marine Pollution in Kuwaiti Waters}

All interviewees, except KI-3 (the governmental employee), agreed there is a high level of pollution in Kuwait and this is partly responsible for the decline in fish stocks in Kuwaiti waters, though their opinions varied about the level of pollution and the extent of the danger it poses to fish stocks. KI-1 stated that the Kuwaiti sea is very polluted and constitutes a serious threat to fish and human health and agreed with KI-2 and KI-3 that the Kuwaiti government prefers not to state the dangers of pollution in Kuwaiti waters to avoid panicking the public. These KIs said although the government does not object to the publication of research studies about pollution because generally the public do not read scientific reports, it does not allow researchers to speak to the media in detail about pollution. However, the lead researcher of this study has been interviewed on Kuwaiti TV four times, on different TV channels (both private and governmental TV), and he has never been told not to talk about marine pollution matters. KI-2 claimed that the Kuwaiti sea is very polluted, but because Kuwait has not laid down national standards for measuring pollution levels, he has used KISR's standards; these are the same as the international criteria which align with the criteria adopted by the Clinical Laboratory and
Standard Institute (CLSI, 2014). On this measure, he said, Kuwait has reached a high level of the widely accepted international standard of pollution, meaning that the Kuwaiti sea is very polluted. However, KI-3 disagreed, arguing that while the Kuwaiti sea is polluted, the level of pollution is below the international threshold level, and the EPA is constantly monitoring and controlling pollution, meaning that Kuwaiti waters are safe.

\section{The Effect of Pollution on Fish Stocks}

Nine KIs (all but KI-3 and KI-5) agreed that pollution is one of the main causes of the fish stock decline in Kuwaiti waters. KI-1 explained that pollution in Kuwait affects the fish in three ways: first, certain types of fish adapt to the pollution and live with it, but they will manifest changes in behavior, quality, life span, reduction in immune system efficiency, and color. KI-2 (a researcher in the KISR) said his studies showed there has been a massive change in fish behavior- i.e., in swimming activity and nutritional health-because of oil pollution. During the interview, which took place in a KISR lab, KI-2 showed pictures and samples of several fish species, revealing that fish such as Zobaidi changed to a darker color and smaller size during the year. Also the samples showed a difference in the swimming behavior of the fish as the interviewee claimed that the Zobaidi and Maid fish species exhibited faster and more aggressive movement than in the past and this is an effect of disturbance in the fish's psychological system due to pollution from oil. Second, some fish are killed by the pollution in Kuwaiti waters and there are at least two massive fish kills every year. Third, some fish are being driven away from polluted Kuwaiti waters. All three effects contribute to fish stock decline. KI-4 said his fishing business has been damaged by the reduction in fish availability in Kuwait because of pollution, pointing out that some fish species such as Shim no longer exist in Kuwaiti waters, and are not seen in the market. However, by looking at the figures for fish production in Kuwait (see section Decline in Fish Stocks in Kuwaiti Waters), we can see a small mean increase of about 138 tons in Shim production in 2018. KI6 claimed that pollution in the Kuwaiti sea is significant and is definitely damaging the fish stock, but he could not provide solid evidence about how much of the fish stock is harmed and exactly which species are being affected.

A more granulated picture of the effect of pollution on fish stocks was obtained from fishers' knowledge of specific areas. KIs-8,-9,-10, and -11 were asked about the fishing areas for each species of fish that has declined, in the hope that knowing the fishing area for each fish species would give more specific explanations for the decline-for example, if the area is near sewage stations or oil platforms. The following table identifies the fishing areas for each of the declined fish species in Kuwait, as verified by the interview data from fishermen and fish business owners KIs-4, $-8,-9,-10$, and -11 .

KIs-4, $-8,-9,-10$, and -11 said the above fish species and the shrimp are now traveling away from the Kuwaiti coasts to the high seas. The fish in the North, such as Zobaidi, used to be found in the North near the coast but now they can be found in the Northeast, near Failkah and Miskan Islands. Fish species in the South are moving to the Southeast near the Southern islands. The following maps show the locations mentioned above such as 
the fishing areas for each fish species, the Jaber-bridge, factories, sea ports, islands and other locations quoted in this section. The sea charts were retrieved from the Garmen Navigation System, and fishing areas were retrieved using shared locations from 40 fishermen in addition to the interviewed fishermen in this study (Figures 5-7).

From the above maps, we can see that most of the fishing areas are near the coasts where there are industrial plants such as power stations, or islands such as Failaka where there is an air force base in Figure 5. The fisher KIs reported that many sources of pollution in the fishing areas mentioned on the maps, such as sewage, constructions, chemicals from factories or even noise pollution, are responsible for driving the fish away from their original habitats either through migration or massive fish kill. All of the fishers stated that they needed to travel to furtheraway locations in the high seas for those fish species because they can no longer find them near the coast because of the pollution. However, Alqattan et al. (2020) showed that the abovementioned areas are being heavily fished by illegal fishing vessels, so pollution may not be the sole reason for the fish migration.

\section{Sources of Pollution in Kuwaiti Waters}

The interviewees identified six sources of pollution in Kuwaiti waters. First, KI-1 said that the high salinity of waters in the North was due to the shortage of fresh waters from Shat AlArab. Salinity levels of $28-30$ ppt were tolerable (ppt is the total amount of dissolved salt in grams per kilograms of water), but the current level is $40 \mathrm{ppt}$, and this is dangerous for many species of fish. Second, KI-6 said sewage discharge was found in collected water samples from several stations in Kuwait, containing rare types of pollution and bacteria. KI-6 alleged that some firms in Kuwait illegally connect their waste pipes to the rain run-off drain stations to discharge raw sewage into the sea, while some hospitals do the same with their discharges of blood samples, medicines (including antibiotics) and cleaning products, which seriously damage the marine environment and spread marine disease. KI-3 acknowledged there is a problem with sewage discharge but claimed the KEPA is working well to deal with it and the level of sewage pollution is within the range of acceptability on their standards. Third, KI-1 and KI4 said ships' chemical waste deposited in Kuwaiti waters is one of the most serious pollutants in Kuwait. KI-1 said that some of the ships are Kuwaiti and some are foreign, and they dump ballast water and chemicals with impunity because of the lack of monitoring by the Kuwaiti authorities. KI-1 explained that oxygen in the water declines when chemicals are dumped in it, and this increases bacteria which use more oxygen leaving insufficient levels for the fish, leading to their deaths, as happened in large numbers in 1999 and 2001. Fourth, KI-1 claimed that the Jaber Bridge has had a negative impact on Kuwaiti waters because it causes a delay of water flow during high and low waters which affects the fish in Kuwait Bay and is one of the main causes of fish kill. All fishers and fishing companies noticed the decline resulting from the turbulence of water near the Jaber Bridge. However, KI-3 denied this claim, saying the EPA analyzed the likely environmental impact of the Jaber Bridge project before its approval and required the company to take mitigating action to correct/prevent possible pollution before beginning construction.

Fifth, KI-2 held that oil spills in Kuwaiti waters are major sources of pollution in Kuwait, which reduced fish stocks, and said many accidental oil spills are attributable to oil tankers belonging to Iran, Iraq, Kuwait and other countries because of the large volume of shipping to and from oil export terminals in the area. Another source of oil spillage is the oil piers in the South of Kuwait which have an oil spill almost every month. For example, KI-2 claimed that in 2017, there was a huge oil spill from a pier in the South that was worse than the oil spills that occurred during the Iraqi invasion in 1990. He also said that oil spills in Kuwait are not announced by the government unless they are reported in the social media. However, KI-3 argued that there is no problem of oil spills in Kuwait because the KEPA and its emergency teams are quick to deal with all spills efficiently. KI-3 also claimed that most oil spills in the region are in Iraq's waters, not Kuwait's waters, and so the KEPA has nothing to do with them. Sixth, KI-4 said that a company in Kuwait conducts earthquake surveys in Kuwaiti waters using underwater SONARs and phones and exploding bombs under the surface, and every time they operate in Kuwaiti waters there is a major fish kill.

\section{Government Action to Deal With Marine Pollution}

According to several KIs, governmental action to tackle marine pollution has been ineffective as Kuwait faces several fish kills every year and the spectacle of dirty water (chemicals and spills), beaches (plastic and rubbish), and islands (rubbish, plastic and food leftover) can be seen by the naked eye at those locations. KI-1, KI-2, and KI-4 said the main reason for this ineffectiveness is that officials in the KEPA are not qualified to understand the problem of marine pollution. KI-2 said KEPA staff who are employed to investigate do not have sufficient knowledge to conduct such investigations nor to activate response procedures.

KI-1 claimed another reason for failure to deal with marine pollution lay at the door of the private companies which are contracted by KEPA to carry out environmental impact assessments (EIAs) of major marine projects such as the Jaber Bridge. KI-1 claimed that some of the private companies hired by KEPA to carry out assessments for major development projects are owned by KEPA staff and faculty members of Kuwait University. The implication of KI-1's claim is that the EIAs conducted by these private companies are not rigorous enough to deal with the environmental risks of pollution, and projects are given approval that should not have been granted. KI-1 also claimed KEPA has only one employee to collect the water samples from all the stations in Kuwait and test them, so it has to depend on unreliable private companies to take samples and provide analyses. KI-3 denied this assertion, and said KEPA have their own labs and research vessel, but according to the SAB, these labs and research vessel, which cost huge amounts of money, have never been used (State Audit Bureau, 2018).

A third reason given for ineffective action against marine pollution is that the response of the emergency teams charged with the responsibility of dealing with oil spills is poor. For 


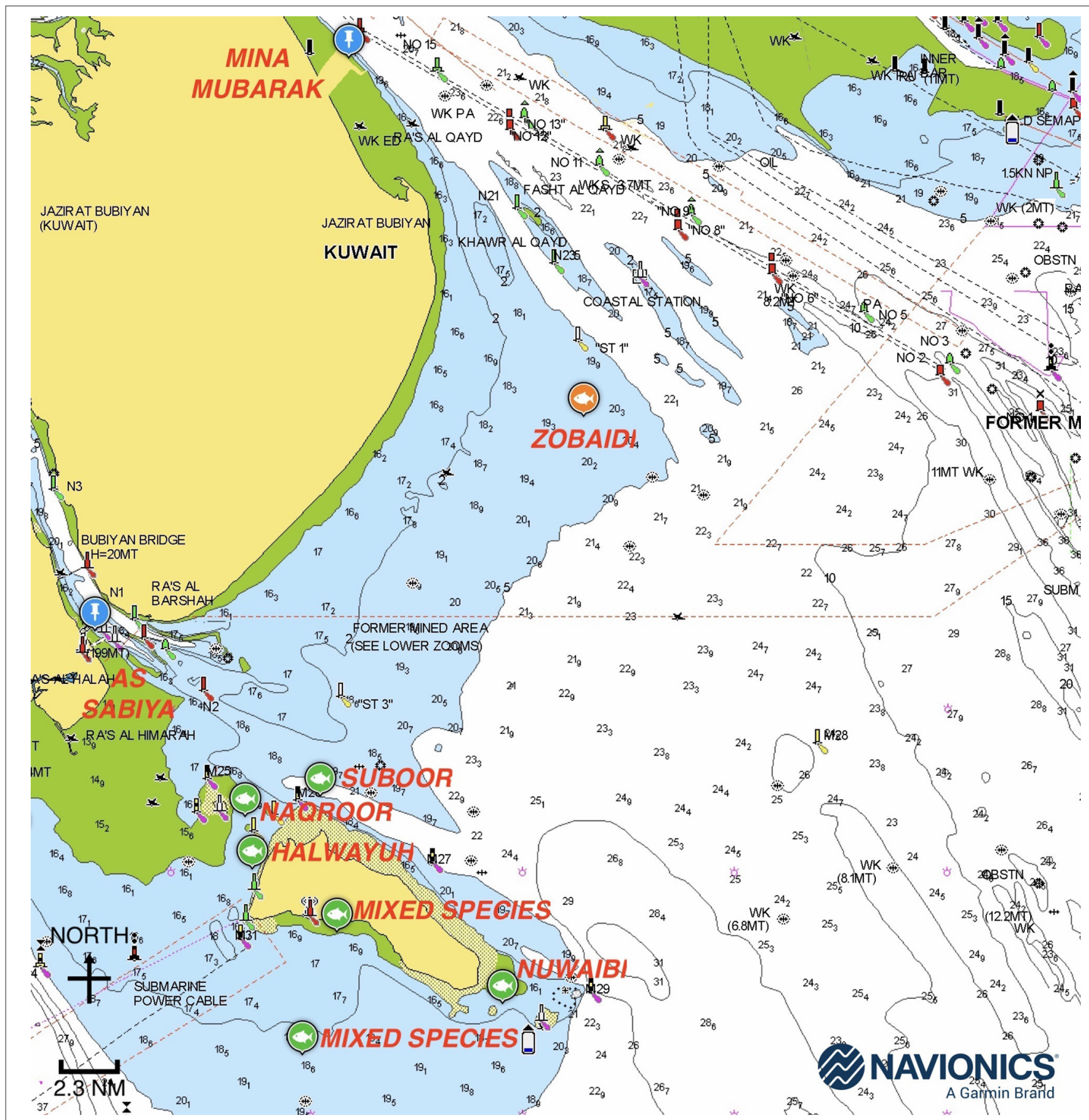

FIGURE 5 | The Northern Region of the Kuwaiti Coast Chart, showing the fishing areas for several fish species and showing several landmarks for pollution sources. Source: Garmin Navigation System and Navionics (https://www.navionics.com/usa/charts/features/garmin). This map is for reference only and not to be used for Navigation.

example, KI-2 claimed that, although the emergency team in the Kuwaiti Oil Company (KOC) is qualified to deal with oil spills, they apply a chemical dispersant to deal with the spills at a rate which damages the water more than the spill itself did. The team should apply the dispersant at a ratio of one to ten (i.e., for $1 \mathrm{~g}$ of oil it should apply $0.1 \mathrm{~g}$ of dispersant), but it sprays the dispersant in large quantities on the oil to clear it up as fast as possible, and this excessive amount of chemical dispersant harms fish stocks. KI-2 also said that in most cases, the emergency team does not appear on the scene until many hours after reports of the spills. He claimed one of the incidents happened on a morning during Ramadan, and the emergency team turned up at night, more than 


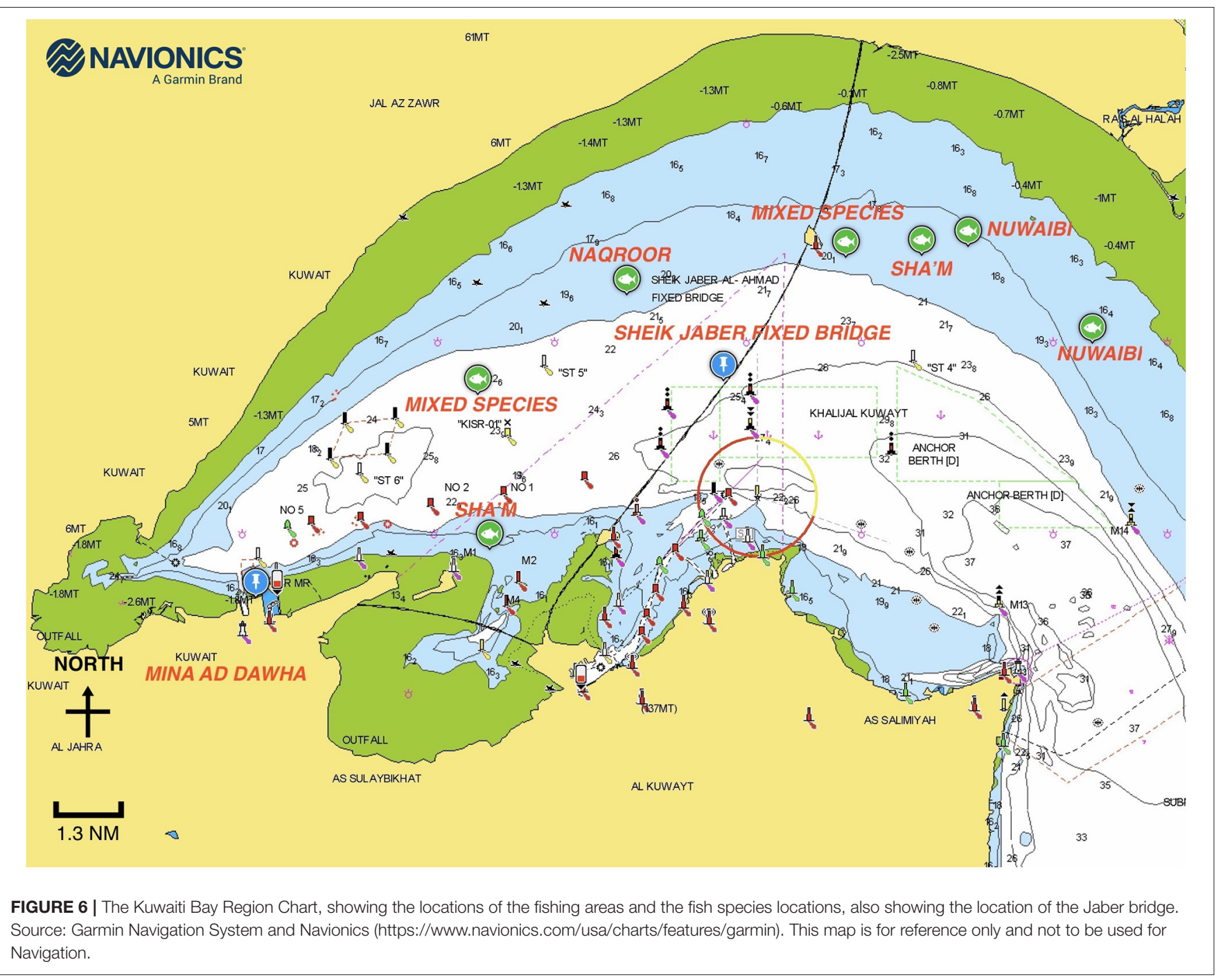

$12 \mathrm{~h}$ after the spill, because they had been fasting during the day. KI-4 stated his fleet of fishing boats frequently spot oil spills in Kuwaiti waters and call out KEPA and KOC emergency teams, but most of the time these teams never show up or they show up hours after the spills. KI-1 and KI-2 said the well-funded Regional Organization for the Protection of the Marine Environment (ROPME) which is head-quartered in Kuwait, is charged with the responsibility of giving warning of any oil spills, but instead they spend their time attending meetings and conferences, and their staff are not qualified for the role of administering an early warning system. However, KI-3 refuted these allegations, stating that the KOC emergency team responds rapidly and effectively to all oil spill calls.

A fourth reason is alleged irresponsible working practices. KI-2 stated that both KEPA and KOC have the resources to counter all types of pollution and spills because they are given generous funding to buy equipment and carry out training, but there is a problem of duplicit working practices. For example, KI-2 claimed that no one in either KEPA or KOC is disciplined for neglecting their duty to investigate tankers which spill oil at sea or pier workers who cause the spills from land. KI-1 alleged that people are keen to work at the EPA because they can go to the shopping malls claiming they do so to monitor environmental offenses like smoking. The Kuwaiti State Audit Bureau (2016, 2018) reported that many employees do not attend their workplace all day or every day or do not attend meetings as required. KI-5 claimed that some employees attend in the morning to sign in with their fingerprints, then return to their homes or go to shopping malls and come back at the end of the working day to sign out with their fingerprints. Another form of alleged duplicity is the conflict of interest between KOC and KEPA. KI-2 said KOC cause oil spills and are meant to clean them up, while KEPA is the body that has to report these spills and take out charges against KOC, but since the two bodies are technically in the same team, no charges are ever brought against KOC. Moreover, KI-6 claimed the Kuwaiti government is itself one of the worst contributors to marine pollution by sewage discharge from, and illegal sewage 


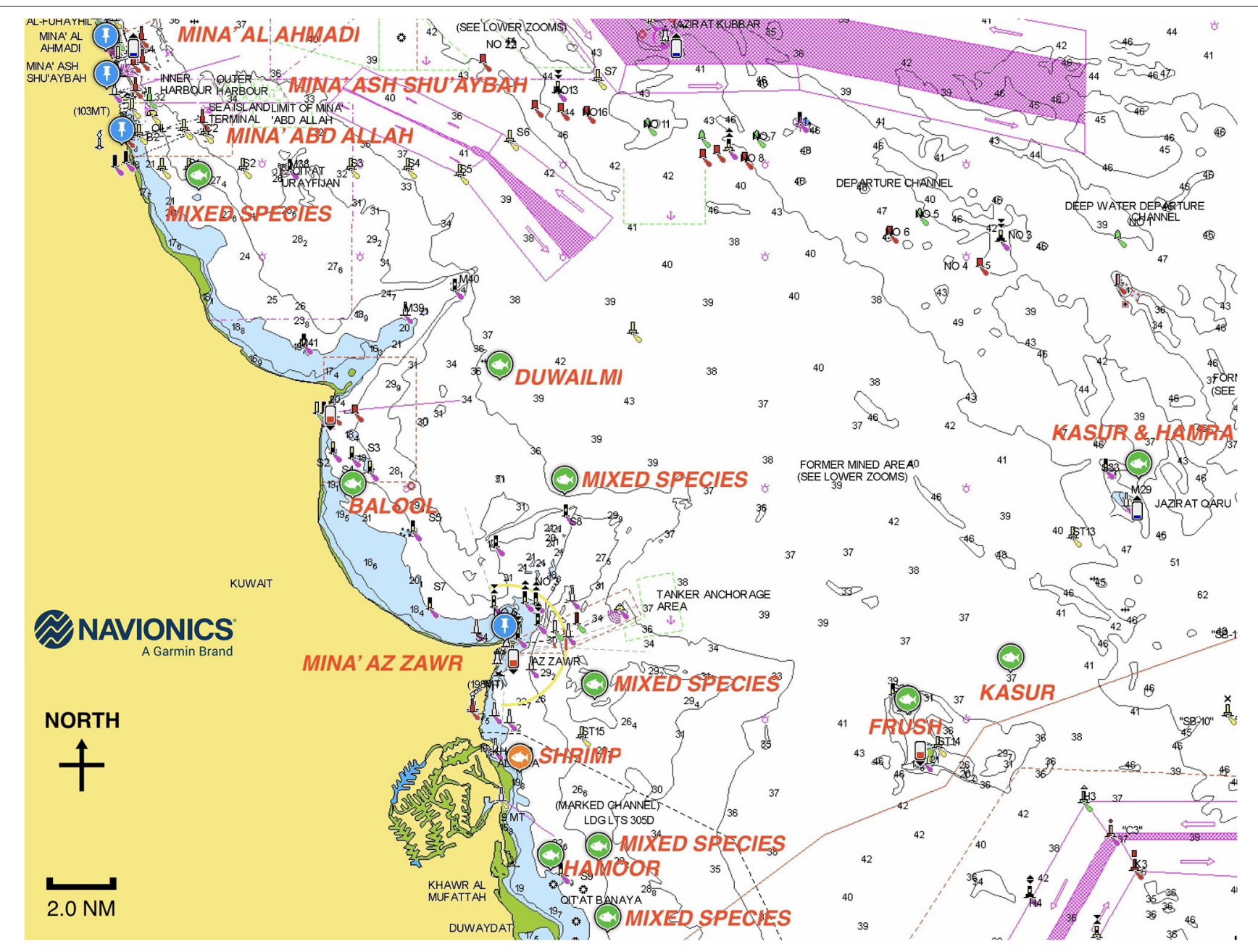

FIGURE 7 | The Southern Region Coast Chart, showing the locations of the fishing areas and the fish species fishing locations. Also showing several pollution sources locations such as Mina Az Zawr harbor. Source: Garmin Navigation System and Navionics (https://www.navionics.com/usa/charts/features/garmin). This map is for reference only and not to be used for Navigation.

connections installed in, departmental buildings, but no action is taken against the government. KI-1 asserted that minutes of KEPA meetings show how staff are more interested in the perks they can obtain from projects-such as attendance at international training courses and conferences-than in the success of the projects themselves.

Fifth, the government was accused of ignoring the advice of expert bodies. For example, KI-1 said KISR informed the government about sewage discharge from Shat Al-Arab, recommending that Kuwait must act to find an international solution or invest in the Iraqi sewage system in the South, but the government never took any action.

\section{KIs' Recommendations}

KIs made many recommendations for reducing pollution in Kuwaiti waters. For example, regarding oil spills and sewage discharge from Iraq, KI-1 suggested that Kuwait should report Iraq to the United Nations for violation of international law. With regard to domestic causes of pollution, KI-6 said steps should be taken to make the Kuwaiti government more aware of the seriousness of the problem by providing more papers, meetings and courses for government members, in order to move issues of marine pollution up the political agenda. KI-1, KI-2, and KI-4 said that combatting conflicts of interest is essential to counter pollution, and that all government members should be banned from owning private companies who carry out environmental impact assessments analysis in order to avoid approving future projects which cause such environmental damage as the Jaber Bridge. KI-1, KI-2, KI-4, and KI-6 argued that Kuwait must improve its public employment system and only recruit people who are qualified, ending the practice of assigning unqualified royal family members to important positions in KEPA and PAAFR. Also, they said the government must not allow members of parliament to influence appointments in the EPA and PAF. KI3 and KI- 5 suggested there should be more coordination between environmental agencies to improve the efficiency of work in dealing with oil spills and sewage discharge. Finally, KI-1, KI2 , and KI-4 suggested that the government must severely punish 


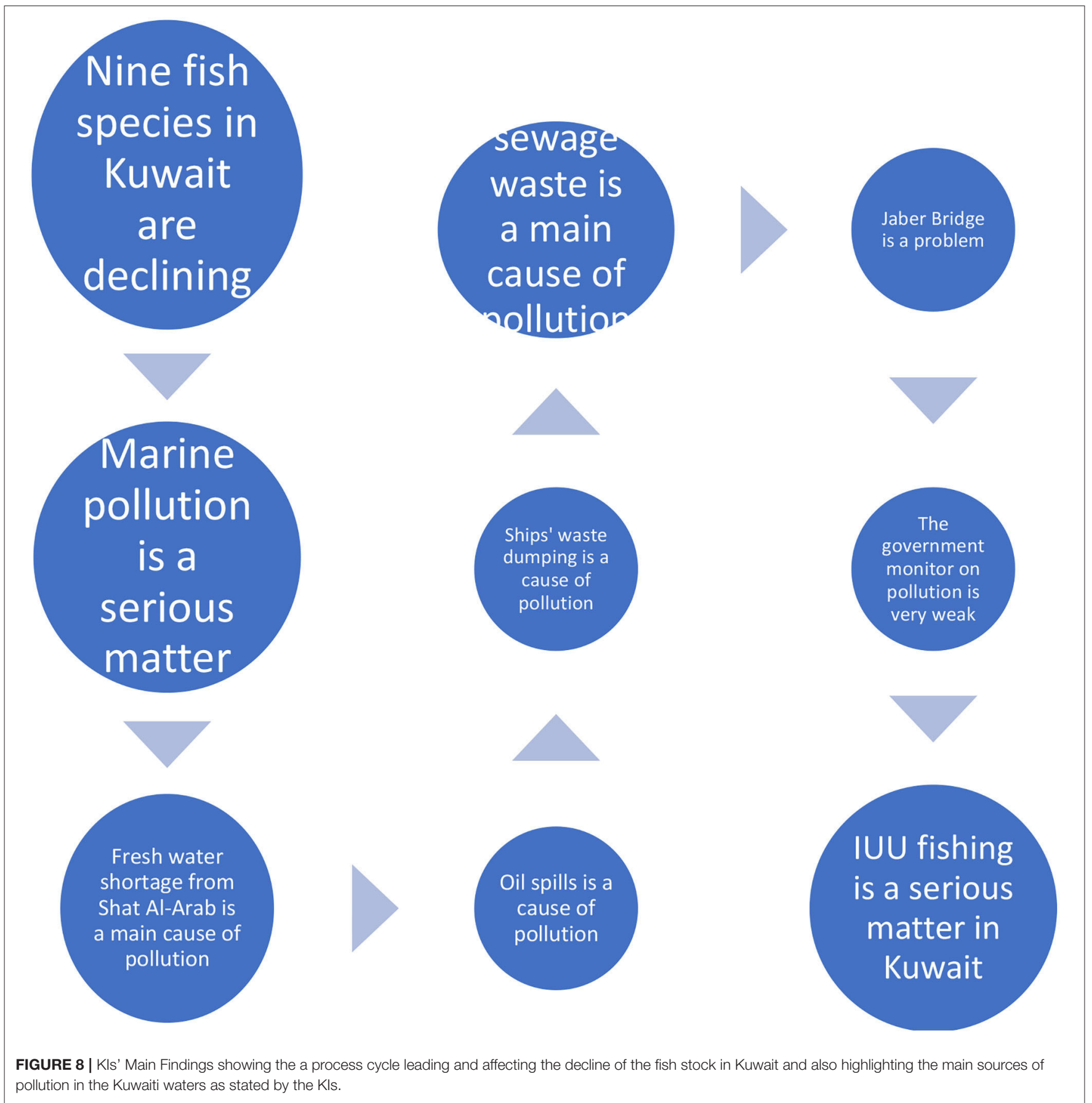

those who violate the environmental law or employees who show lack of urgency in dealing with pollution.

The following figure (Figure 8) summarizes the main contributions from the KIs.

\section{DISCUSSION}

There is a consensus between KIs in this study and previous studies that there is a significant degree of pollution in Kuwaiti waters. Only KI-3, the environmental government employee, rejected this view, arguing that while the Kuwaiti sea is polluted, the level of pollution is below the international threshold level, and because KEPA is constantly monitoring and controlling pollution, Kuwaiti waters are safe for fish. However, KI-3 was unable to provide evidence to support the assertion that the biological and chemical traces found in water samples were safe for fish.

KIs and previous studies also agree on the sources of the pollution, including sewage discharge, oil spills, high salinity, chemical waste from international and local ships, 
and the environmental impacts of infrastructural projects like the Jaber Bridge. Moreover, KIs and previous studies both identify governmental failings which compound the pollution problem, including unqualified regulatory officers, administrative duplicity, inadequate monitoring of pollution levels, poor enforcement of environmental laws, environmental ignorance, little sense of urgency, and lack of political will. The most fundamental of these factors are environmental ignorance, duplicity and the lack of political will, which are linked to each other. Environmental ignorance is evident in the failure of the Kuwaiti government to acknowledge the seriousness of the situation, partly because of the unqualified managers in ministries and agencies, partly because of the limited amount of research carried out into marine pollution in Kuwaiti waters, and partly because of the lack of a spirit of environmental stewardship amongst the public. This, in turn, is due to the country's focus during the last 50 years on the extraction and production of oilthe black gold-rather than the preservation and conservation of the country's other natural resources. Duplicity in Kuwait is many-sided and all-pervasive, and is fed by, and in turn feeds, the vast inequalities of wealth and income in the country. Lack of political will is partly due to ignorance on the part of the government and parliament of the extent of marine pollution in Kuwaiti waters, and partly due to corruption which blocks remedial action.

As a result of these factors, action by the government to reduce marine pollution is more noticeable for its absence than its presence. An illustration of government inaction is provided by CBC (2017) which reported that "the Kuwaiti Public Environment Authority failed to warn the public about a severe [oil spill] disaster." The Kuwaiti President of the Green Life Society alleged the Kuwaiti government blocked all information about the disaster, and this had serious consequences for marine life and fish by delaying remedial action. However, our research in the KEPA library shows this particular allegation is unfounded. The government did not intervene to block information: KEPA is itself selective about the information it releases, arguing that so long as it deals with pollution incidents, it does not need to publicize them and thereby risk public panic.

Finally, previous studies, KIs-4, $-8,-9,-10$, and -11 , and the Kuwaiti government's fish stock statistics all agree that nine of the main commercial fish species in Kuwait have decreased steeply in stock size (see Table 2), especially species in the South of Kuwait where the fish species traveled away from the coast all the way to the high seas and near the Southern Kuwaiti islands. For most KIs (KIs-1,-4,-8,-9,-10, and-11), this decline in fish stocks was linked to increased pollution. Comparing the locations of the pollution sources and their effects on the nine declining fish species in Table 2, we found links between various sources of pollution and reductions in fish species, which seemed to confirm that pollution is the direct cause of the decrease of the fish stock.

After the above analysis of the literature and data from interviews we can answer the study's three research questions(1) what is the current state of health of the marine environment in Kuwait? (2) how does it affect the fishery? (3) and are governmental actions effective in protecting fish stocks from threats to their health? On (1), we found that the Kuwaiti sea
TABLE 2 | The fishing areas for the declining fish species in Kuwait.

\begin{tabular}{|c|c|}
\hline $\begin{array}{l}\text { The declining fish } \\
\text { species }\end{array}$ & The fishing areas for the species \\
\hline 1. Shrimp & $\begin{array}{l}\text { - The South, in mud seabed and near the coast } \\
\text { - The Southern Islands in the mud }\end{array}$ \\
\hline 2. Zobaidi & $\begin{array}{l}\text { - The North, } \\
\text { - The South near Ras Alsalmiyah }\end{array}$ \\
\hline 3. Suboor & - The North \\
\hline 4. Naqroor & $\begin{array}{l}\text { - The North, in shallow waters } \\
\text { - The Kuwaiti bay }\end{array}$ \\
\hline 5. Hamoor & - The South \\
\hline 6. Hamra & - The South \\
\hline 7. Halwayuh & $\begin{array}{l}\text { - The South, and near Qarouh Island } \\
\text { - Between Failaka and Ouhah Island }\end{array}$ \\
\hline 8. Frush & - The South \\
\hline 9. Kasur & - Near the South Islands \\
\hline
\end{tabular}

suffers from a serious degree of pollution which renders the waters unhealthy. The reports showed from the literature and KIs stated that the Kuwaiti sea water quality is poor in the matter of salinity and oxygen levels. On (2), however, we were unable to categorically pin the entire blame for the decline in fish stocks on pollution. We asked ourselves why did pollution only cause a decline in nine commercial fish species? All the other commercial species have not declined, so how were they able to withstand pollution? These questions suggest that there must be some additional reason to account for the decline of the nine species. That additional reason appears to be overfishing. Significantly, those nine declining species are greatly in demand by consumers and therefore targeted by fishers, meaning their fishing areas are highly exploited, and so over-fishing (especially by illegal fishers) is almost certainly another cause, and possibly the main cause, of their decline. On (3) it was found that the Kuwaiti government's lack of control and monitoring is one of the main causes for the matter of marine pollution in Kuwait. This was also reported by the Kuwaiti State Audit Bureau on the review of the Kuwaiti government's policies and practices.

\section{CONCLUSION}

\section{Main Findings}

The main findings of this study are as follows. First, nine main species of fish in Kuwait are sharply declining. Seven of them are South fish species; the other two (Zobaidi and Suboor) are North fish species. Second, the study shows that pollution exists in Kuwaiti waters, and that the main sources of that pollution are (the most dangerous first): sewage discharge which affects the Kuwaiti coast from the Kuwaiti Bay and all the way to the South; oil spills which affect mostly the Southern coasts; chemical waste from local and international ships which occur near the ports in the North, Kuwait Bay and the South; shortage of fresh water from Shat Al-Arab because of the Turkish Anadholian water dams and from Karon River because of the Iranian water dams which affect the coasts in the North; the water desalination station which affects the North and Kuwaiti Bay; and the factories in the South which affect the Southern coasts. Third, while a 
combination of all these pollution sources has contributed to the decrease of the nine fish species, three other factors must also be considered as contributory causes. First, overfishing and illegal fishing are common in Kuwait. Second, duplicity within the employment system of the government's environmental sector has undermined its effectiveness in dealing with marine pollution, not least because of inadequate scientific research and a fake certificate scandal. Third, lack of political salience. Because neither the government nor the public is fully aware of the extent of marine pollution in the Kuwaiti waters, remediation measures are not at the top of the political agenda in the country. So while pollution is a proximate or immediate cause of fish stock decline in the Kuwaiti waters, other proximate or immediate causes include over-fishing and illegal fishing, and the underlying reason why both pollution and overfishing/illegal fishing persist lies in the failings of the country's political system.

\section{Recommendations}

The study recommends the following steps to deal with the impact of marine pollution and other causes of declining fish stocks in Kuwaiti waters:

(1) Dealing with proximate causes

- To introduce anti-microbial resistance (AMR) screening to identify water quality issues and their impacts on both marine life and human health (KI-1)

- To develop a new infrastructure of sewage disposal to prevent raw sewage being discharged into the sea, and in the meantime, to monitor and punish illegal sewage discharge (KIs-2 and-6)

- To improve the efficiency of the oil spills emergency teams and separate them from the oil companies. (KI-2)

- To apply more control and monitoring of the factories in the South and their discharge of waste into the sea. (KIs$1,-2,-4$, and -6 )

- To relocate the desalination station from Subiyah area, close to the bay, to a different location which has less effect on fish species. (KIs-1 and-6)

- To address illegal and over-fishing in Kuwait as a priority, as this could be the primary cause for the fish decline. (KI-7)

(2) Dealing with underlying causes

- To integrate the enforcement organizations to ensure more coordinated action by the navy, coastguards, police, and the KEPA against maritime polluters, over-fishing and IUU fishing, making use of sophisticated surveillance technologies (KIs-1,-2,-6, and-7)

- To eliminate duplicity from environmental impact assessments (EIAs) by forbidding officials from owning private companies which carry out these EIAs. (KI-1)

\section{REFERENCES}

Al-Baz, A., Bishop, J., Al-Husaini, M., and Chen, W. (2018). Gargoor trap fishery in Kuwait, catch rate and species composition. J. Appl. Ichthyol. 34, 867-877. doi: $10.1111 /$ jai.13703

Al-Foudari, H. M., Alsaffar, A. H., Bishop, J. M., Chen, W., Dashti, T., Al-Jazzaf, S. T., et al. (2013). A Comparative Management Strategy for the Long-Term
- To reform the employment system in government departments and public agencies to replace the criterion of nepotism with the principle of merit. (KIS-1,-2, and-6)

- To establish academic teams, in partnerships between the government, universities, and the private sector, to develop research strategies and priorities to deal with marine environmental problems in Kuwait. These teams must consult with all stakeholders to better understand the situation. (KI-2)

- To make decision makers in the government and the parliament more aware of the marine environmental situation, and to provide more coordination between decision makers and scientists. (KIs-1,-2, and-7)

- To promote environmental education in schools and the media in order to develop a sense of environmental stewardship among the public and the political classes. (KIs-2 and-3)

- To encourage the government to liaise with neighboring countries (including GCC states and Iraq, Iran and Turkey) to deal regionally with marine pollution, over-fishing and IUU fishing issues that affect them all. (KI-6)

- To require the government to play a leading role in the Arab League and the United Nations in international efforts to combat marine pollution and IUU. (KI-2)

\section{Limitations}

Two difficulties were faced during this study. First, most Kuwaiti fishing companies do not present their data online, so researchers sometimes have to physically travel to their headquarters to obtain information. Second, part of this study was conducted during the Covid-19 pandemic which made physical visits to gather data extremely difficult.

\section{AUTHOR CONTRIBUTIONS}

MA conducted the fieldwork and interviewed the stakeholders in Kuwait to address the gaps in the research. TSG was responsible for the restructuring and editing of the first draft of the paper to improve its coherence, rigor, and transform it into a publishable article. Both authors contributed to the writing of the article and approved the submitted version.

\section{ACKNOWLEDGMENTS}

This study could not have been carried out without the help of the Kuwaiti navy who supported the fieldwork by providing ships and personnel. We are very grateful to the naval authorities. Also, many thanks to the Kuwaiti coastguards, the KISR and the EPA who assisted the research with data and information. The authors are great full the benefit from the academic services provided by Newcastle University.

Sustainability of Kuwait's Shrimp Stocks. K. I. f. S. R. Report, Vol. 4. Kuwait Institute for Scientific Research.

Al-Husaini, M., Bishop, J. M., Al-Foudari, A. F., and Al-Baz. (2015). A review of the status and development of Kuwait's fisheries. Mar. Pollut. Bull. 100, 597-606. doi: 10.1016/j.marpolbul.2015.07.053

Ali, A., and Chidambaram, S. (2021). Assessment of trace inorganic contaminates in water and sediment to address its impact on common 
fish varieties along Kuwait bay. Environ. Geochem. Health 43, 855-883. doi: 10.1007/s10653-020-00559-6

Aljazeerah News (2017). Emergency Teams Battle to Contain Oil Pill Off Kuwait. Oil Analysts Estimate About 35,000 Barrels of Crude May Have Leaked Into Waters Near a Kuwaiti-Saudi Offshore Oilfield. Available online at: https:/www.aljazeera.com/news/2017/08/ emergency-teams-battle-oil-spill-kuwait-170813075307529.html (accessed April 2, 2019).

Almatar, S., and Chen, W. (2010). Deformities in silver pomfret pampus argenteus caught from Kuwait waters. Chin. J. Oceanol. Limnol. 28, 1227-1229. doi: 10.1007/s00343-010-0082-3

Al-Miqdadi, K., and Al-Hoosh, A. (2016). The Protection of Marine Environment, pp. 646. Available online at: https://books.google.co.uk/ books? $\mathrm{id}=009 \mathrm{mDwAAQBAJ}$ andprintsec $=$ frontcover $-\mathrm{v}=$ onepageandqandf $=$ false (accessed January 12, 2020).

Al-Mutairi, N., Abahussain, A., and Al-Battay, A. (2014). Environmental assessment of water quality in Kuwait bay. Int. J. Environ. Sci. Dev. 5, 527-532. doi: 10.7763/IJESD.2014.V5.539

Alqattan, M. (2018). The Kuwaiti Islands' Documentary. Available online at: https://www.youtube.com/watch?v=DB95MsA6OHsandt=112s (accessed July $25,2018)$.

Alqattan, M. E. A., Gray, T. S., and Stead, S. M. (2020). The illegal, unreported and unregulated fishing in Kuwait: problems and solutions. Marine Policy 116:103775. doi: 10.1016/j.marpol.2019.103775

Al-Saad, H. T., and Salman, N. A. (2012). "Status of oil pollution in the Arabian Gulf and Shatt Al-Arab Estuary: a review," in Coastal Environments: Focus on Asian Regions, Vol. 7, ed V. Subramanian (New Delhi: Springer), 36-47.

Al-Sarawi, H. A., Jha, A. N., Baker-Austin, C., Al-Sarawi, M. A., and Lyons, B. P. (2018). Baseline screening for the presence of antimicrobial resistance in E. coli isolated from Kuwait's marine environment. Mar. Pollut. Bull. 129, 893-898. doi: 10.1016/j.marpolbul.2017.10.044

Alshemmari, H. (2021). An overview of persistent organic pollutants along the coastal enviroment of Kuwait. Open Chem. 19, 149-156. doi: 10.1515/chem-2021-0198

Al-Yamani, F., Polikarpov, I., and Saburova, M. (2020). Marine life mortalities and harmful alga blooms in the Northern Arabian Gulf. Aquat. Ecosyst. Health Manag. 23, 196-209. doi: 10.1080/14634988.2020.1798157

Al-Zaidan, A. S. Y., Al-Mohanna, S. Y., and George, P. (2013). Status of Kuwait's fishery resources: assessment and perspective. Mar. Policy 38, 1-7. doi: 10.1016/j.marpol.2012.05.013

Ben-Hasan, A., Al-Husaini, M., and Walters, C. (2017). Adaptive management of declining fisheries: when is it worth trying to rebuild stocks through fishery regulation? Mar. Policy 85, 107-113. doi: 10.1016/j.marpol.2017.08.027

Bird, E. (2010). Encyclopedia of The World's Coastal Landforms. Melbourne, VIC: University of Melbourne.

CBC (2017). Kuwait Battles Oil Spill in Persian Gulf Waters. Available online at: https://www.cbc.ca/news/world/kuwait-battles-oil-spill-in-persiangulf-waters- 1.4245702 (accessed February 10, 2021).

CEIC (2019). Kuwait Average Price: Fish. Available online at: https://www.ceicdata. com/en (accession April 1, 2019).

CLSI (2014). Clinical and Laboratory Standards Institute publication document M100-S24. Performance standards for antimicrobial susceptibility testing. Twenty Fourth Informational Supplement. Available online at: file://campus/home/home02/nma150/Downloads/CLSIM100-24-2014\%2 0 (1).pdf

CSB (2021). Statitics of Fish Wealth. Available online at: https://www.csb.gov.kw/ Pages/Statistics_en?ID=43andParentCatID $=4$ (accessed July 18, 2018).

Devlin, M. J., Massoud, M. S., Hamid, S. A., Al-Zaidan, A., Al-Sarawi, H., AlEnezi, M., et al. (2015). Changes in the water quality conditions of Kuwait's marine waters: long term impacts of nutrient enrichment. Mar. Pollut. Bull. 100, 607-620. doi: 10.1016/j.marpolbul.2015.10.022
Edmonds, N. J., Al-Zaidan, A. S., Al-Sabah, A. A., Le Quesne, W. J. F., Devlin, M. J., Davison, P. I., et al. (2021). Kuwait marine biodiversity: qualitative assessment of indicator habitats and species. Mar. Pollut. Bull. 163, 1-15. doi: 10.1016/j.marpolbul.2020.111915

Hosseini, H., Saadaoui, I., Moheimani, N., Al Saidi, M., Al Jamali, F., Al Jabri, H., et al. (2021). Marine health of the arabian gulf: drivers of pollution and assessment approaches focusing on desalination activities. Mar. Pollut. Bull. 164:112085. doi: 10.1016/j.marpolbul.2021. 112085

Kuwait News Agency (2018). EPA: No Oil Spills in Kuwait Bay. Retrieved from: https://www.kuna.net.kw/ArticleDetails.aspx?id=2750467\&language=en (accessed December 3, 2018).

Lyons, B. P., Devlin, M. J., Hamid, S. A. A., Al-Otiabi, A. F., AlEnezi, M., Massoud, M. S., et al. (2015). Microbial water quality and sedimentary faecal sterols as markers of sewage contamination in Kuwait. Mar. Pollut. Bull. 100, 689-698. doi: 10.1016/j.marpolbul.2015. 07.043

Mahdi, K. (2018). "Kuwait's plan for the future," in Paper Presented at the International Conference on Innovational and Economic Diversification in GCC's National Development Plans (Kuwait). Available online at: https://kif.kdipa.gov. kw/wp-content/uploads/khalid-mahdi-english.pdf (accessed March 20, 2019).

Marex (2017). Kuwait Cleans Up Oil Spill in Persian Gulf. Available online at: https://www.maritime-executive.com/article/kuwait-battles-oil-spill-nearsaudi-border (accessed December 3, 2018).

Naser, H. A. (2014). Marine Ecosystem Diversity in the Arabian Gulf: Threats and Conservation. Available online at: https://www.intechopen.com/ books/biodiversity-the-dynamic-balance-of-the-planet/marine-ecosystemdiversity-in-the-arabian-gulf-threats-and-conservation (accessed January 25, 2020).

State Audit Bureau (2016). Annual Report Report of the Audit Bureau Part II on the Results of the Examination and Review on the Implementation of Budgets of the Annexes and Their Final Accounts for the Fiscal Year 2015-2016, Vol. 2, 1-353. Kuwait: State Audit Bureau.

State Audit Bureau (2018). Annual Report Report of the Audit Bureau Part II on the Results of the Examination and Review on the Implementation of Budgets of the Annexes and Their Final Accounts for the Fiscal Year 2017-2018. Kuwait: State Audit Bureau.

Toumi, H. (2019). Forged Degree Scandal Rocks Kuwait [Press Release]. Available online at: https://gulfnews.com/world/gulf/kuwait/forged-degreescandal-rocks-kuwait-1.63080818 (accessed January 12, 2021).

Trading Economics (2019). Kuwait GDP Annual Growth Rate. Available online at: https://tradingeconomics.com/kuwait/gdp-growth-annual (accessed June 4, 2019).

Uddin, S., Aba, A., Fowler, S. W., Behbehani, M., Ismaeel, A., Al-Shammari, H., et al. (2015). Radioactivity in the Kuwait marine environmentbaseline measurements and review. Mar. Pollut. Bull. 100, 651-661. doi: 10.1016/j.marpolbul.2015.10.018

UNCLOS (1982). United Nations Convention on the Law of the Sea. New York, NY: United Nations. Available online at: http://www.un.org/Depts/los/convention agreements/texts/unclos/unclos_e.pdf (accessed September 4, 2018).

Conflict of Interest: The authors declare that the research was conducted in the absence of any commercial or financial relationships that could be construed as a potential conflict of interest.

Copyright (C) 2021 Alqattan and Gray. This is an open-access article distributed under the terms of the Creative Commons Attribution License (CC BY). The use, distribution or reproduction in other forums is permitted, provided the original author(s) and the copyright owner(s) are credited and that the original publication in this journal is cited, in accordance with accepted academic practice. No use, distribution or reproduction is permitted which does not comply with these terms. 


\section{APPENDIX A}

Appendix A | The semi structured interview questions.

\section{The interview contents:}

1. What is your general insight about the marine pollution in Kuwait? Is there pollution or not?

2. If so, to what extension is there pollution? Has it reached a dangerous level?

3. Do you know what fish species have declined because of the pollution?

4. What are the effects of the pollution on the fish stocks in Kuwait?

5. What are the sources of pollution in Kuwait?

6. Are there any controls over the ships that dump chemical waste?

7. What type of chemical waste do the ships dump?

8. Do the sewage stations in Kuwait reprocess sewage before discharging to sea?

9. Are you aware of any illegal sewage disposal?

10. Is the sewage treatment system in Kuwait not good enough?

11. In general what do you think about the health of the fish stock in Kuwait?

12. What else has contributed to declining fish stocks other than sewage waste and chemical waste?

13. What are the causes behind the annual fish kill in Kuwait?

14. Does the government know about these pollution problems?

15. Is there uranium pollution in Kuwait?

16. What are the priorities for the Kuwaiti government in combatting pollution?

17. Are you aware of high salinity because of the Shat Al-Arab?

18. Does your organization coordinate with the government on pollution issues?

19. On a scale of 1 to 10 where ten is high, what is your ranking of the level or pollution in Kuwait and the level of effectiveness of government measures to combat it?

20. How do you rate the EPA in the matter of effectiveness?

21. What are the impacts of constructions and dredging on the marine environment in Kuwait? For example, the Jaberbridge?

22. How well is the fish production business doing in Kuwait?

23. How is the fish market affected by the fish decline? 